\title{
Effect of Oxidation State of Iron Ions on the Viscosity of Alkali Silicate Melts
}

\author{
Takeshi OSUGI, ${ }^{1,2)}$ Sohei SUKENAGA, ${ }^{1,3) *}$ Yosuke INATOMI, ${ }^{1)}$ Yoshiaki GONDA, ${ }^{4)}$ Noritaka SAITO ${ }^{1)}$ \\ and Kunihiko NAKASHIMA ${ }^{1)}$
}

1) Department of Materials Science and Engineering, Kyushu University, 744, Motooka, Nishi-ku, Fukuoka, 819-0395 Japan.

2) Department of Decommissioning and Waste Management, Nuclear Science Research Institute, Tokai Research and Development Center, Japan Atomic Energy Agency, 2-4, Shirakatashirane, Tokai-mura, Naka-gun, Ibaraki, $319-1195$ Japan.

3) UPR3079, CEMHTI-CNRS, 1D avenue de la Recherché Scientifique, 45071 Orléans cedex 2, France.

4) Formerly Graduate Student, Department of Materials Science and Engineering, Kyushu University. Now at Nippon Steel \& Sumitomo Metal Corporation, 1, Kimitsu, Chiba, 299-1141 Japan.

(Received on July 17, 2012; accepted on October 3, 2012)

\begin{abstract}
Understanding the changes in viscosity due to the different oxidation states of iron ions is important for simulating phenomena related to molten slags and also for understanding the structure of iron-oxidecontaining silicate melts. However, these viscosity changes are not well understood. Here, we show the viscosity changes of $\mathrm{R}_{2} \mathrm{O}-\mathrm{SiO}_{2}-\mathrm{Fe}_{\mathrm{x}} \mathrm{O}(\mathrm{R}=\mathrm{Li}, \mathrm{Na}$, or $\mathrm{K})$ melts due to changes in the oxidation states of the iron ions by systematically varying the oxygen partial pressure using several Ar-based gases at $1773 \mathrm{~K}$. The initial compositions of the samples were $30 \mathrm{R}_{2} \mathrm{O}-60 \mathrm{SiO}_{2}-10 \mathrm{Fe}_{2} \mathrm{O}_{3}(\mathrm{~mol} \%)$, and the ratio of $\mathrm{Fe}^{3+}$ to $\mathrm{Fe}^{2+}$ in the $\mathrm{R}_{2} \mathrm{O}-\mathrm{SiO}_{2}-\mathrm{Fe}_{\mathrm{x}} \mathrm{O}$ melts increased with increasing oxygen partial pressure in all samples. Meanwhile, the viscosity of all the $\mathrm{R}_{2} \mathrm{O}-\mathrm{SiO}_{2}-\mathrm{Fe}_{\mathrm{x}} \mathrm{O}$ melts decreased with increasing $\mathrm{Fe}^{2+}$ to total-Fe ratio. The data indicate that the increase in the amount of $\mathrm{Fe}^{2+}$ ions, which behave as network modifiers, would result in depolymerization of the silicate melts. It should also be noted that the viscosity of the melts increased in the order of alkali cationic radius ( $\mathrm{K}>\mathrm{Na}>\mathrm{Li}$ ) when the ratios of $\mathrm{Fe}^{2+}$ to $\mathrm{Fe}^{3+}$ in the melts were comparable. This was due to the change in the coordination structure of $\mathrm{Fe}^{3+}$ in the melts. Not only the oxidation state of the iron ions but also the coordination structure of $\mathrm{Fe}^{3+}$ may be important for understanding the viscosity.
\end{abstract}

KEY WORDS: viscosity; alkali ferrosilicate melts; redox equilibria of Fe; oxygen partial pressure.

\section{Introduction}

Iron-oxide-containing silicate melts are important molten materials in various industrial processes carried out at elevated temperature, such as glass making and pyrometallurgical extraction (as slags). They are also major components in many geological processes in the Earth's mantle. In pyrometallurgical processes, the viscosity of the slag is an important physical property for estimating the fluidity of the molten slags and clarifying the reaction kinetics related to the slag at elevated temperature. Since the viscosity of the slag is a structure-sensitive property, viscosity is also important for understanding the microstructure of the slags at elevated temperature.

It is well known that the oxidation state of the iron ions $\left(\mathrm{Fe}^{2+}\right.$ and $\left.\mathrm{Fe}^{3+}\right)$ in silicate melts changes depending on the melting temperature, basicity of the melt, and the oxygen partial pressure. ${ }^{1-8)}$ In particular, the oxidation states of the iron ions in metallurgical slags can easily change depending on the conditions of the processes in which the slags are employed. ${ }^{9)}$ In addition, $\mathrm{FeO}\left(\mathrm{Fe}^{2+}\right)$ is known to form octa-

* Corresponding author: E-mail: sukenaga@zaiko.kyushu-u.ac.jp DOI: http://dx.doi.org/10.2355/isijinternational.53.185 hedra $\left(\mathrm{Fe}^{2+}(6)\right)$ and behaves as a network modifier, ${ }^{10)}$ while $\mathrm{Fe}_{2} \mathrm{O}_{3}\left(\mathrm{Fe}^{3+}\right)$ plays an intermediate role between the network former and the network modifier ${ }^{10,11)}$ since it forms both tetrahedra $\left(\mathrm{Fe}^{3+}(4)\right)$ and octahedra $\left(\mathrm{Fe}^{3+}(6)\right)$. Therefore, the ratio of the $\mathrm{Fe}^{2+}$ content to the total amount of $\mathrm{Fe}\left(\mathrm{Fe}^{2+} /\right.$ total$\mathrm{Fe}$ ) in the melts should affect the viscosity. Viscosity data on iron-oxide-containing slags with different $\mathrm{Fe}^{2+} /$ total-Fe values are important for optimizing the practical operation of high-temperature metallurgical processes.

From this background, several researchers ${ }^{12-15)}$ have studied the effect of $\mathrm{Fe}^{2+} /$ total-Fe on the viscosity of iron-oxidecontaining slags. Table 1 shows a summary of the research works related to the effect of $\mathrm{Fe}^{2+} /$ total-Fe on the viscosity. As shown in Table 1, different effects of $\mathrm{Fe}^{2+} /$ total-Fe on the viscosity were reported by the different researchers. In these previous studies, all the researchers employed $\mathrm{CO}_{2}$-based gases to control the oxygen partial pressure. However, it is well known that $\mathrm{CO}_{2}$ gas easily dissolves into oxide melts when the basicity of the melt is high. Hara et al. ${ }^{5)}$ mentioned that the $\mathrm{Fe}^{2+}-\mathrm{Fe}^{3+}$ equilibria of the $\mathrm{BaO}-\mathrm{Fe}_{\mathrm{x}} \mathrm{O}$ system were influenced by $\mathrm{CO}_{2}$ gas dissolution into the melts. Moreover, Sumita et al. ${ }^{16)}$ reported that the viscosity of the $\mathrm{CaO}-\mathrm{Fe}_{\mathrm{x}} \mathrm{O}$ system increased as $\mathrm{CO}_{2}$ gas dissolved into the melts. These 
Table 1. Summary of changes in viscosity of iron-oxide-containing melts for different oxidation states of iron ions reported by several researchers.

\begin{tabular}{|c|c|c|c|}
\hline $\begin{array}{l}\text { Authors } \\
\text { (year) }\end{array}$ & $\begin{array}{c}\text { System } \\
\text { (contact material) }\end{array}$ & Atmosphere & Results \\
\hline $\begin{array}{l}\text { Kaiura et al. }{ }^{12)} \\
\quad(1977)\end{array}$ & $\begin{array}{c}\mathrm{CaO}-\mathrm{SiO}_{2}-\mathrm{Fe}_{\mathrm{x}} \mathrm{O} \\
\text { ternary system }(\mathrm{Mo})\end{array}$ & $\mathrm{CO}-\mathrm{CO}_{2}$ & $\begin{array}{l}\text { Viscosity changed } \\
\text { only slightly with } \\
\mathrm{Fe}^{2+} \text { total-Fe }\end{array}$ \\
\hline $\begin{array}{l}\text { Seki and } \\
\text { Oeters }^{13)} \\
(1984)\end{array}$ & $\begin{array}{c}\mathrm{CaO}-\mathrm{SiO}_{2}-\mathrm{Fe}_{\mathrm{x}} \mathrm{O} \\
\text { ternary system }(\mathrm{Pt}-18 \mathrm{Rh})\end{array}$ & $\begin{array}{c}\text { Air and } \\
\mathrm{CO}_{2}\end{array}$ & $\begin{array}{l}\text { Viscosity increased } \\
\text { with } \mathrm{Fe}^{2+} / \text { total-Fe }\end{array}$ \\
\hline $\begin{array}{l}\text { Dingwell }{ }^{14)} \\
(1991)\end{array}$ & $\begin{array}{l}\left(\mathrm{R}_{2} \mathrm{O} \text { or } \mathrm{RO}\right)-\mathrm{SiO}_{2}-\mathrm{Fe}_{\mathrm{x}} \mathrm{O} \\
\text { ternary system }(\mathrm{Pt}-20 \mathrm{Rh})\end{array}$ & $\mathrm{CO}-\mathrm{CO}_{2}$ & $\begin{array}{l}\text { Viscosity decreased } \\
\text { with } \mathrm{Fe}^{2+} / \text { total-Fe }\end{array}$ \\
\hline $\begin{array}{l}\text { Nowok }^{15)} \\
(1995)\end{array}$ & $\begin{array}{c}\mathrm{CaO}-\mathrm{SiO}_{2}-\mathrm{Al}_{2} \mathrm{O}_{3}-\mathrm{Fe}_{\mathrm{x}} \mathrm{O} \\
\text { based multicomponent } \\
\text { system }(\mathrm{Pt})\end{array}$ & $\mathrm{CO}-\mathrm{CO}_{2}$ & $\begin{array}{l}\text { Viscosity decreased } \\
\text { with } \mathrm{Fe}^{2+} / \text { total-Fe }\end{array}$ \\
\hline
\end{tabular}

two previous reports indicate that utilization of $\mathrm{CO}_{2}$ gas could make the viscosity change ambiguous.

In the present work, we selected an iron-oxide-containing alkali silicate system for a fundamental study of iron-oxidecontaining slags. The effect of the oxygen partial pressure on the viscosity of the melts was examined using the rotating cylinder method. Ar-based gases, which are known to be slightly soluble to silicate melts, ${ }^{17)}$ were employed to control the oxygen partial pressure when we examined the effect of $\mathrm{Fe}^{2+} /$ total-Fe on the viscosity. Viscosity changes due to changes in the oxidation states of iron ions and in the kind of alkali oxides present were explored.

\section{Experimental}

\subsection{Sample Preparation}

Table 2 shows the initial compositions of the samples used for the viscosity measurements. The samples were prepared from reagent grade $\mathrm{SiO}_{2}, \mathrm{Fe}_{2} \mathrm{O}_{3}, \mathrm{Li}_{2} \mathrm{CO}_{3}, \mathrm{Na}_{2} \mathrm{CO}_{3}$, and $\mathrm{K}_{2} \mathrm{CO}_{3}$ powders (supplier: Sigma Aldrich, Inc.). These reagents were precisely weighed to form the given compositions and were thoroughly mixed in a mullite mortar. The mixtures were placed in a Pt crucible and then melted at $1773 \mathrm{~K}$ in a resistance furnace for 30 minutes under air. Finally, the melts were quenched on a copper plate. Then, the quenched samples were crushed into powders, and these powders were employed for viscosity measurements. Since alkali carbonates were employed as the raw materials for the samples, there is a possibility that dissolved $\mathrm{CO}_{2}$ can be present in the quenched samples. Richet and his coworkers ${ }^{18,19)}$ have reported the effect of melting temperature on the dissolved $\mathrm{CO}_{2}$ concentration in the potassium silicate glasses, which were made from $\mathrm{K}_{2} \mathrm{CO}_{3}$ and $\mathrm{SiO}_{2}$. Bourgue and Richet ${ }^{19)}$ reported that the concentration of dissolved $\mathrm{CO}_{2}$ in the $56.9 \mathrm{SiO}_{2}-43.1 \mathrm{~K}_{2} \mathrm{O}(\mathrm{mol} \%)$ glass decreased with increasing melting temperature. In their study, dissolved $\mathrm{CO}_{2}$ concentration in the glass after melting at $1773 \mathrm{~K}$ (melting time: $15-30 \mathrm{~min}$ ) was reported as a small value of $0.22 \mathrm{wt} \%$. In the present study, the samples were also made by melting the mixture of the reagents at $1773 \mathrm{~K}$ for $30 \mathrm{~min}$. We believe that the dissolved $\mathrm{CO}_{2}$ concentration in our samples could be low enough to have only slight influence on the viscosity of its melts.
Table 2. Initial compositions (mol\%) of the samples for viscosity measurement.

\begin{tabular}{cccccc}
\hline Sample & $\mathrm{SiO}_{2}$ & $\mathrm{Fe}_{2} \mathrm{O}_{3}$ & $\mathrm{Li}_{2} \mathrm{O}$ & $\mathrm{Na}_{2} \mathrm{O}$ & $\mathrm{K}_{2} \mathrm{O}$ \\
\hline $\mathrm{LSF}$ & 60 & 10 & 30 & - & - \\
$\mathrm{NSF}$ & 60 & 10 & - & 30 & - \\
$\mathrm{KSF}$ & 60 & 10 & - & - & 30 \\
\hline
\end{tabular}

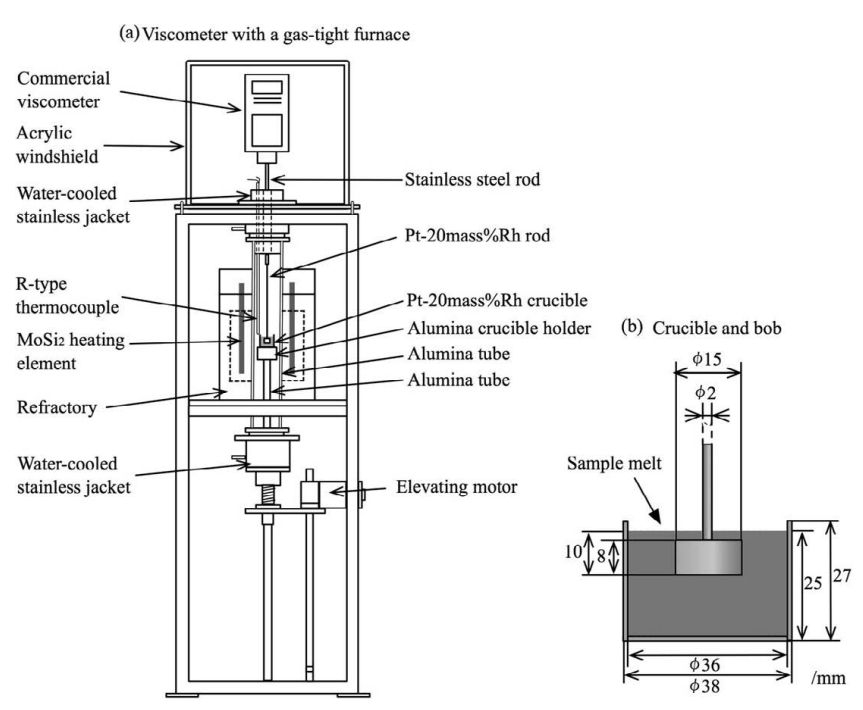

Fig. 1. Schematic illustrations of (a) the apparatus for viscosity measurement and (b) the dimensions of the crucible and bob.

\subsection{Viscosity Measurement}

\subsubsection{Apparatus}

The viscosity of the samples was measured using the rotating cylinder method ${ }^{20,21)}$ in the present study. Figure 1(a) shows schematic illustrations of a rotating-inner-cylinder viscometer with a gas-tight furnace, which allowed us to do the measurements under well-defined oxygen partial pressures. An electric resistance furnace with six U-shaped $\mathrm{MoSi}_{2}$ heating elements was employed for heating. An acrylic box mounted on the top of the furnace, as shown in Fig. 1(a), was used to isolate the system from the outside atmosphere during the measurements. The dimensions of the crucible and the bob are illustrated in Fig. 1(b). The crucible and bob employed in the experiments were both of Pt-20 mass\%Rh. The relative torque exerted on the inner cylinder (bob) was acquired using a commercial viscometer. The apparent viscosity of the sample was calculated based on the relationship between the viscosity and the relative torque value obtained beforehand using several kinds of silicone oil (viscosity range: $0.10-1.0$ Pas) as a reference. After that, the measured apparent viscosity was corrected for the thermal expansion of the crucible and the bob using the following equation:

$$
\eta=\frac{\eta^{\prime}}{(1+\alpha T)^{3}}
$$

where $\eta, \eta^{\prime}, \alpha$, and $T$ are the viscosity, apparent viscosity, thermal expansion coefficient, and absolute temperature, respectively.

The viscometer was calibrated at high temperature using standard reference materials for high-temperature viscosity measurements (SRM2 type slags). ${ }^{22)}$ The chemical compo- 
Table 3. Chemical compositions of standard reference materials for high-temperature viscosity measurements (mass\%). We employed a standard material composed of the major components in the well-known SRM2. ${ }^{22}$

\begin{tabular}{lccccccccc}
\hline & $\mathrm{SiO}_{2}$ & $\mathrm{Al}_{2} \mathrm{O}_{3}$ & $\mathrm{Li}_{2} \mathrm{O}$ & $\mathrm{K}_{2} \mathrm{O}$ & $\mathrm{Na}_{2} \mathrm{O}$ & $\mathrm{MgO}$ & $\mathrm{CaO}$ & $\mathrm{TiO}_{2}$ & $\mathrm{P}_{2} \mathrm{O}_{5}$ \\
\hline SRM2 & 63.70 & 14.40 & 20.60 & 0.13 & 0.40 & $<0.10$ & 0.40 & $<0.10$ & $<0.01$ \\
Present study & 63.95 & 14.45 & 20.67 & 0.13 & 0.40 & - & 0.40 & - & - \\
\hline
\end{tabular}

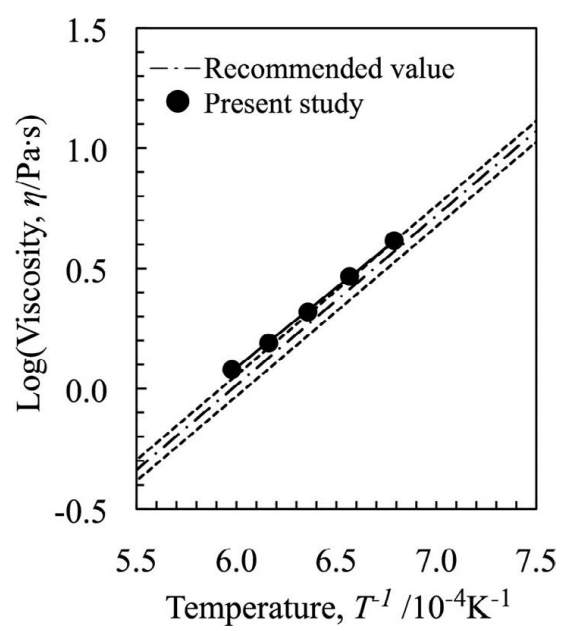

Fig. 2. Temperature dependence of the viscosity of the standard reference material for high-temperature viscosity measurements. The dashed lines represent $\pm 10 \%$ uncertainty from the recommended value ${ }^{22)}$ for SRM2.

sitions of the standard reference materials are listed in Table 3. Figure 2 shows the temperature dependence of the viscosity for the standard reference material. As shown in Fig. 2 , the results of the high-temperature calibration values fit the recommended value well. ${ }^{22}$ )

\subsubsection{Procedure}

The atmospheres employed in the present study are listed in Table 4, including their oxygen partial pressures. The oxygen partial pressures were examined using a $\mathrm{ZrO}_{2}-\mathrm{CaO}$ oxygen probe. We measured the viscosity under continuously varying oxygen partial pressures by changing the atmospheres in the sequence of air, $\mathrm{Ar}-1 \% \mathrm{O}_{2}$, Ar, high-purity $\mathrm{Ar}$, and $\mathrm{Ar}-1 \% \mathrm{H}_{2}$.

The sample powders were placed in the Pt-20 mass\%Rh crucible and heated up to $1773 \mathrm{~K}$ under air. Then, the inner cylinder (Pt-20 mass\%Rh bob) was immersed in the sample melts, after which we started turning the inner cylinder to monitor the relative torque. The viscosity of the sample melts could be continuously collected during the melting time. We changed the atmosphere after the viscosity of the samples melts became constant under each atmosphere. The experimental conditions used for the viscosity measurements are listed in Table 5. The errors in the viscosity measurements were within $\pm 5 \%$.

After the viscosity measurements, the crucible was removed from the bottom of the furnace. Then the sample melt was poured on a copper plate and quenched to a glass by pressing with another copper plate. We chemically analyzed the quenched samples. Table 6 shows the final compositions of the samples with analyzing method. The amount of each component changed only slightly during the
Table 4. Oxygen partial pressures of the atmospheres employed for the viscosity measurements. The oxygen partial pressures of the Ar-based gases were determined using a $\mathrm{ZrO}_{2}-\mathrm{CaO}$ oxygen probe.

\begin{tabular}{cccccc}
\hline Atmosphere & Air & $\mathrm{Ar}-1 \% \mathrm{O}_{2}$ & $\mathrm{Ar}$ & High-purity $\mathrm{Ar}$ & $\mathrm{Ar}-1 \% \mathrm{H}_{2}$ \\
\hline$p\left(\mathrm{O}_{2}\right) / \mathrm{atm}$ & $2.0 \times 10^{-1}$ & $1.3 \times 10^{-2}$ & $7.1 \times 10^{-5}$ & $3.2 \times 10^{-6}$ & $1.6 \times 10^{-10}$ \\
\hline
\end{tabular}

Table 5. Experimental conditions for the viscosity measurements.

\begin{tabular}{c|c} 
Temperature & $1773 \mathrm{~K}$ \\
Atmospheres & $\begin{array}{c}\text { Air, } \mathrm{Ar}-1 \% \mathrm{O}_{2}, \mathrm{Ar}, \\
\text { Sample weight }\end{array}$ \\
high-purity $\mathrm{Ar}, \mathrm{Ar}-1 \% \mathrm{H}_{2}$ \\
Immersion depth of inner cylinder & $50.0-70.0 \mathrm{~g}$ \\
Revolution speed of inner cylinder & $10.0 \mathrm{~mm}$ \\
\hline
\end{tabular}

Table 6. Chemical compositions (mol\%) of the samples after the viscosity measurements. The samples were quenched from $1773 \mathrm{~K}$ after the viscosity measurements.

\begin{tabular}{cccccc}
\hline Sample & $\mathrm{SiO}_{2}{ }^{\mathrm{a}}$ & $\mathrm{Fe}_{2} \mathrm{O}_{3}{ }^{\mathrm{b}}$ & $\mathrm{Li}_{2} \mathrm{O}^{\mathrm{c}}$ & $\mathrm{Na}_{2} \mathrm{O}^{\mathrm{c}}$ & $\mathrm{K}_{2} \mathrm{O}^{\mathrm{c}}$ \\
\hline $\mathrm{LSF}$ & 60.33 & 9.73 & 29.94 & - & - \\
$\mathrm{NSF}$ & 60.01 & 9.96 & - & 30.03 & - \\
$\mathrm{KSF}$ & 59.72 & 9.43 & - & - & 30.85
\end{tabular}

${ }^{a} \mathrm{SiO}_{2}$ content was analyzed using gravimetry.

${ }^{b}$ Iron oxide content was expressed as $\mathrm{Fe}_{2} \mathrm{O}_{3}$ content, which was calculated from the total $\mathrm{Fe}$ content. The total-Fe content in the samples was determined using a titration method with ethylenedinitrilo-tetraacetic acid (EDTA).

${ }^{c}$ The alkali oxide content was determined using atomic absorption spectrometry.

experiments.

\subsection{Analysis of the Oxidation States of Iron Ions in the Samples}

We synthesized the samples for oxidation state analysis of iron ions by the same procedure as those for viscosity measurements as mentioned above. The samples were melted in a Pt-20 mass\%Rh crucible (sample amount, $20 \mathrm{~g}$; internal diameter of the crucible, $36 \mathrm{~mm}$ ) for $270 \mathrm{~min}$ under each of the atmosphere (air, Ar- $1 \% \mathrm{O}_{2}$, Ar, high-purity Ar or Ar$1 \% \mathrm{H}_{2}$ ) using the same furnace for the viscosity measurement (Fig. 1(a)). Since the viscosity of the sample melts became constant after 50-165 min of melting under each atmosphere (as described in the following section (Fig. 3)), a melting time of $270 \mathrm{~min}$ was sufficient for the sample to equilibrate with the oxygen in the gas phase at $1773 \mathrm{~K}$ under each atmosphere. After that the crucible was removed from the bottom of the furnace. Then the sample melt was poured on a copper plate and quenched to a glass by pressing with another copper plate to enhance the cooling rate. In the previous study, one of the authors reported that the cooling rate of this method was estimated as $260 \mathrm{~K} / \mathrm{s}^{23}$ ) Wilke et al. ${ }^{24)}$ reported that the oxidation state of iron ions were not affected by cooling rate when the cooling rate was higher than $2.5 \mathrm{~K} / \mathrm{s}$. Therefore, it is believed that cooling rate of $260 \mathrm{~K} / \mathrm{s}$ does not affect the oxidation state of iron ions in the original melts.

The oxidation states of the iron ions for these quenched 


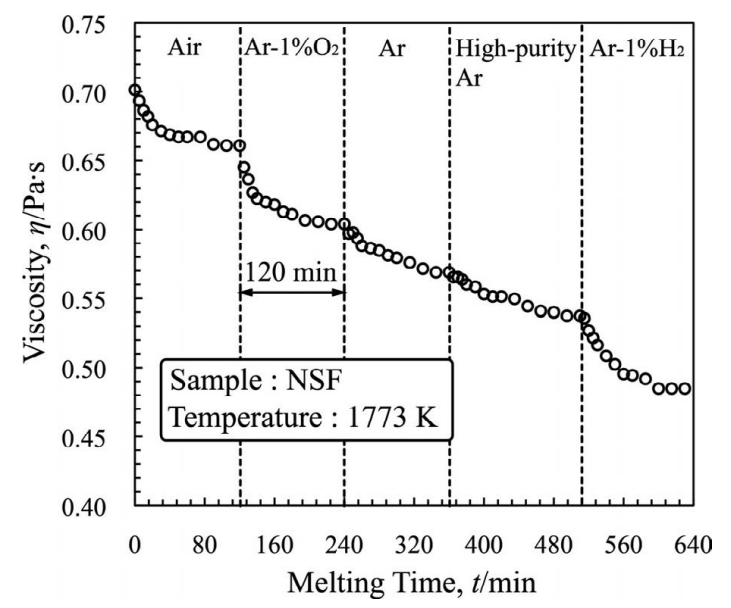

Fig. 3. Changes in viscosity of the NSF melts with melting time at $1773 \mathrm{~K}$. We changed the atmospheres after the viscosity of the melts became constant at each oxygen partial pressure.

vitreous samples were quantitatively determined by wet chemical analysis. In this analysis, the $\mathrm{Fe}^{2+}$ content was determined using a titration method with potassium dichromate. The $\mathrm{Fe}^{3+}$ content was calculated by subtracting the $\mathrm{Fe}^{2+}$ content from the initial total-Fe content.

\section{Results and Discussion}

\subsection{An Example of Viscosity Change during the Mea- surements}

Figure 3 shows the change in the viscosity of the NSF melt during the melting time at $1773 \mathrm{~K}$ as an example. As shown in Fig. 3, the viscosity of the melts decreased with melting time under each atmosphere. It should be noted that the viscosity of the NSF melt decreased with melting time even under air. In a previous paper, ${ }^{25}$ similar phenomena were observed in the $\mathrm{CaO}-\mathrm{SiO}_{2}-\mathrm{Fe}_{\mathrm{x}} \mathrm{O}$ system. In that paper, we clarified that this phenomenon was due to an increase in the amount of octacoordinated $\mathrm{Fe}^{3+}$ ions $\left(\mathrm{Fe}^{3+}(6)\right)$ that behave as network modifiers. Therefore, the viscosity decrease during melting under air should also be due to an increase in $\mathrm{Fe}^{3+}(6)$ in the present study. When the atmosphere was changed from air to $\mathrm{Ar}-1 \% \mathrm{O}_{2}$, the viscosity started to decease again during the melting time, and the viscosity became constant after 120 min of melting under Ar$1 \% \mathrm{O}_{2}$ atmosphere. This indicates that it takes around 120 min to achieve $\mathrm{Fe}^{2+}-\mathrm{Fe}^{3+}$ equilibration. Similar phenomena were observed for all kinds of atmospheres and samples. However, the duration required for equilibration depends on the atmosphere and the composition and ranges from 50 to $165 \mathrm{~min}$. There was a tendency for the duration to be shorter for the LSF samples than for the NSF and KSF samples, and the viscosity of the LSF samples was lower than for the other systems. The difference between the equilibration durations required for NSF and KSF was small. After the samples were melted until the viscosities became constant, the constant viscosity was employed as the equilibrated value under each atmosphere.

\subsection{Oxidation State of Iron Ions in the Samples}

Figure 4 shows the ratios of $\mathrm{Fe}^{3+}$ to $\mathrm{Fe}^{2+}\left(\mathrm{Fe}^{3+} / \mathrm{Fe}^{2+}\right)$ in the $\mathrm{R}_{2} \mathrm{O}-\mathrm{SiO}_{2}-\mathrm{Fe}_{\mathrm{x}} \mathrm{O}$ glasses quenched from $1773 \mathrm{~K}$ as a func-

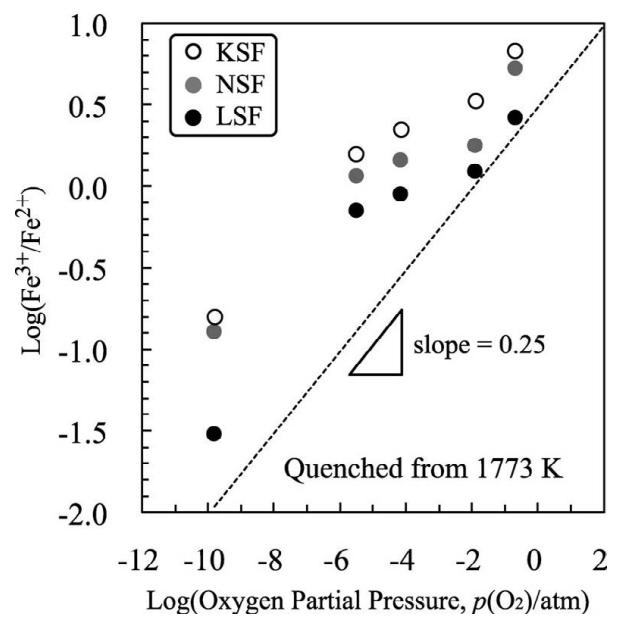

Fig. 4. Effect of oxygen partial pressure, $p\left(\mathrm{O}_{2}\right)$, on the ratio of $\mathrm{Fe}^{3+}$ to $\mathrm{Fe}^{2+}$ in the $\mathrm{R}_{2} \mathrm{O}-\mathrm{SiO}_{2}-\mathrm{Fe}_{\mathrm{x}} \mathrm{O}(\mathrm{R}=\mathrm{Li}, \mathrm{Na}, \mathrm{K})$ glasses quenched from $1773 \mathrm{~K}$. All samples were melted long enough to equilibrate with the oxygen in the gas phases before being quenched with copper plates. The dashed line represents the ideal slope of 0.25 .

tion of the oxygen partial pressure. The $\mathrm{Fe}^{3+} / \mathrm{Fe}^{2+}$ value increased with increasing oxygen partial pressure in all systems. In general, $\mathrm{Fe}^{3+}$ ions exist in several kinds of complex anions such as $\mathrm{FeO}^{+}, \mathrm{Fe}_{2} \mathrm{O}_{5}{ }^{4-}, \mathrm{FeO}_{3}{ }^{3-}$, and $\mathrm{FeO}_{4}{ }^{5-}$ in silicate melts. ${ }^{26)}$ Morinaga et al. ${ }^{26)}$ reported that $\mathrm{Fe}^{3+}$ ions mainly existed as $\mathrm{FeO}_{3}{ }^{3-}$ or $\mathrm{FeO}_{4}{ }^{5-}$ in the $\mathrm{R}_{2} \mathrm{O}-\mathrm{SiO}_{2}-\mathrm{Fe}_{\mathrm{x}} \mathrm{O}(\mathrm{R}=\mathrm{Li}$, $\mathrm{Na}, \mathrm{K})$ glasses. If the $\mathrm{Fe}^{3+}$ ions in the present samples are assumed to exist in $\mathrm{FeO}_{3}{ }^{3-}$ complex anions, the $\mathrm{Fe}^{2+}-\mathrm{Fe}^{3+}$ redox equation can be expressed as follows: ${ }^{27}$

$$
\mathrm{Fe}^{2+}(\text { liq. })+\frac{1}{4} \mathrm{O}_{2}(\text { gas })+\frac{5}{2} \mathrm{O}^{2-}(\text { liq. })=\mathrm{FeO}_{3}^{3-}(\text { liq. }) . .
$$

As shown in Eq. (2), the value of $\mathrm{Fe}^{3+} / \mathrm{Fe}^{2+}$ depends on the oxygen partial pressure of the gas phase and the activity of the $\mathrm{O}^{2-}$ ions in the liquid phase, namely, the basicity. The increase in $\mathrm{Fe}^{3+} / \mathrm{Fe}^{2+}$ indicates that reaction (2) shifts to the right with an increase in the oxygen partial pressure or the activity of $\mathrm{O}^{2-}$. When the effect of $\mathrm{O}^{2-}$ ions on the redox state is neglected for simplicity, the reaction between iron oxides in the melts and oxygen can be expressed as follows:

$$
\mathrm{FeO}(\text { liq. })+\frac{1}{4} \mathrm{O}_{2}(\text { gas })=\mathrm{FeO}_{1.5}(\text { liq. })
$$

From Eq. (3), the equilibrium constant $K$ can be expressed by the following Eq. (4):

$$
K=\frac{a_{\mathrm{FeO}_{1.5}}}{a_{\mathrm{FeO}} \cdot p\left(\mathrm{O}_{2}\right)^{1 / 4}}
$$

where $a_{i}$ and $p\left(\mathrm{O}_{2}\right)$ represent the activity of component $i$ and the oxygen partial pressure, respectively. Equation (4) can be converted into Eq. (5) when the temperature is constant:

$$
\log \left(\frac{a_{\mathrm{FeO}_{1.5}}}{a_{\mathrm{FeO}}}\right)=0.25 \log \left(p\left(\mathrm{O}_{2}\right)\right)+A
$$

where $A$ is constant. If we assume that the $\mathrm{FeO}_{1.5}\left(\mathrm{Fe}^{3+}\right)$ and $\mathrm{FeO}\left(\mathrm{Fe}^{2+}\right)$ components mix ideally in the melts, a plot of $\log \left(\mathrm{Fe}^{3+} / \mathrm{Fe}^{2+}\right)$ against $\log \left(p\left(\mathrm{O}_{2}\right)\right)$ will be linear with a slope of 0.250 (drawn as a dashed line in Fig. 4). In the present study, the relationship between $\log \left(\mathrm{Fe}^{3+} / \mathrm{Fe}^{2+}\right)$ and $\log \left(p\left(\mathrm{O}_{2}\right)\right)$ 
shown in Fig. 4 was not consistent with the slope of the ideal relationship, especially in the lower oxygen partial pressure region. Similar phenomena were reported by Jimbo et al. ${ }^{1)}$ They suggested there is a possibility that the observed oxygen partial pressure is different from that of the gas phase around the sample melts. Since we also employed the oxygen partial pressure of the exhaust gas from the furnace, there is the same possibility in this work.

As shown in Fig. 4, the value of $\mathrm{Fe}^{3+} / \mathrm{Fe}^{2+}$ in the samples increased in the order of the cationic radius of the alkali cations $(\mathrm{K}>\mathrm{Na}>\mathrm{Li}$ ) when the oxygen partial pressures were comparable. Since an increase in basicity corresponds to an increasing negative charge (electron density) on the oxygen atoms, basic oxides (network modifiers) have a greater tendency to liberate $\mathrm{O}^{2-}$ ions when they react with other species. The number of liberated $\mathrm{O}^{2-}$ ions, which is related to the electron-donor power of the oxygen atoms, should be positively correlated with the activity of the $\mathrm{O}^{2-}$ ions. It is difficult to directly observe the activity of $\mathrm{O}^{2-}$ in the melts. However, Duffy and Ingram ${ }^{28)}$ established an optical basicity measurement that could be used to quantify the relative electron-donor power of the oxygen atoms in the system through the measurement of the wave number shift in the $s$ $p$ absorption spectra of the probe ions (such as $\mathrm{Pb}^{2+}$ ) in the solvent system. In other words, we can create a quantitative scale of activity of $\mathrm{O}^{2-}$ ions by using the optical basicity. Duffy $^{29)}$ calculated the theoretical optical basicity of the $\mathrm{R}_{2} \mathrm{O} \cdot 2 \mathrm{SiO}_{2}(\mathrm{R}=\mathrm{Li}, \mathrm{Na}, \mathrm{K})$ system, which is the solvent of the present $\mathrm{R}_{2} \mathrm{O}-\mathrm{SiO}_{2}-\mathrm{Fe}_{\mathrm{x}} \mathrm{O}$ system, and the theoretical optical basicity was found to be in the order of $\mathrm{K}_{2} \mathrm{O} \cdot 2 \mathrm{SiO}_{2}>$ $\mathrm{Na}_{2} \mathrm{O} \cdot 2 \mathrm{SiO}_{2}>\mathrm{Li}_{2} \mathrm{O} \cdot 2 \mathrm{SiO}_{2}$. Therefore, the increase in $\mathrm{Fe}^{3+} /$ $\mathrm{Fe}^{2+}$ with increasing cationic radius of the alkali cation is due to the increase in the activity of $\mathrm{O}^{2-}$ in the silicate melts with increasing alkali cationic radius.

\subsection{Viscosity Changes with $\mathrm{Fe}^{2+} /$ total-Fe}

Figure 5 shows the effect of $\mathrm{Fe}^{2+} /$ total-Fe on the viscosity (equilibrated value) of the $\mathrm{R}_{2} \mathrm{O}-\mathrm{SiO}_{2}-\mathrm{Fe}_{\mathrm{x}} \mathrm{O}$ melts. The viscosity of the melts decreased with increasing $\mathrm{Fe}^{2+} /$ total-Fe in all the melts. The data indicate that the increase in the amount of $\mathrm{Fe}^{2+}$ ions, which behave as network modifiers, would result in depolymerization of the silicate melts. It

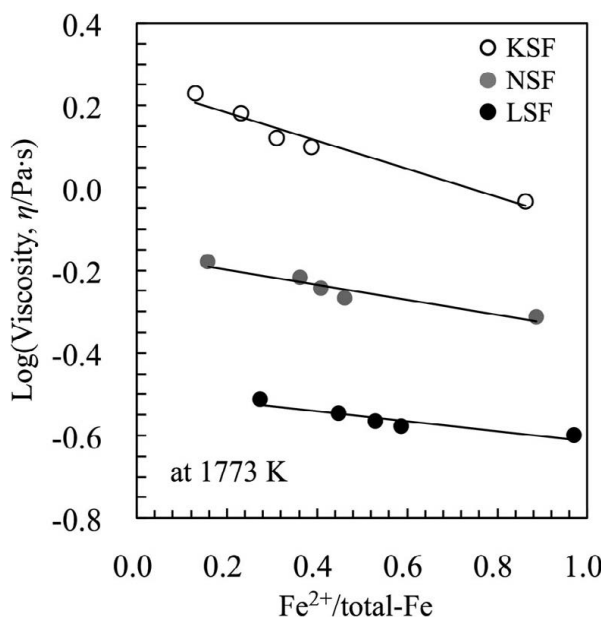

Fig. 5. Viscosity variation of the $\mathrm{R}_{2} \mathrm{O}-\mathrm{SiO}_{2}-\mathrm{Fe}_{\mathrm{x}} \mathrm{O}(\mathrm{R}=\mathrm{Li}, \mathrm{Na}, \mathrm{K})$ melts as a function of the ratio of $\mathrm{Fe}^{2+}$ to total-Fe at $1773 \mathrm{~K}$. should be also noted that the viscosity of the melts increased in the order of the alkali cationic radius $(\mathrm{K}>\mathrm{Na}>\mathrm{Li})$ when the $\mathrm{Fe}^{2+} /$ total-Fe in the melts was comparable. To make clear the effect of the kind of alkali cation on the viscosity, the viscosities of $\mathrm{R}_{2} \mathrm{O}-\mathrm{SiO}_{2}-\mathrm{Fe}_{\mathrm{x}} \mathrm{O}$ melts with $\mathrm{Fe}^{2+} /$ total- $\mathrm{Fe}=$ $0.3\left(\mathrm{Fe}^{3+} /\right.$ total- $\left.\mathrm{Fe}=0.7\right)$ were calculated based on interpolation of the data shown in Fig. 5. Figure 6 shows the relationship between the viscosity of the $\mathrm{R}_{2} \mathrm{O}-\mathrm{SiO}_{2}-\mathrm{Fe}_{\mathrm{x}} \mathrm{O}$ melts and the cationic radius of the alkali cations at $1773 \mathrm{~K}$, compared with that for the $\mathrm{R}_{2} \mathrm{O} \cdot 2 \mathrm{SiO}_{2}(\mathrm{R}=\mathrm{Li}, \mathrm{Na}, \mathrm{K})$ system measured by Bockris et al. ${ }^{30)}$ The viscosity for both systems increased linearly with increasing cationic radius, while the viscosity variation against cationic radius of the $\mathrm{R}_{2} \mathrm{O}-\mathrm{SiO}_{2}-$ $\mathrm{Fe}_{\mathrm{x}} \mathrm{O}$ melts was larger than that for the $\mathrm{R}_{2} \mathrm{O} \cdot 2 \mathrm{SiO}_{2}(\mathrm{R}=\mathrm{Li}$, $\mathrm{Na}, \mathrm{K})$ system. In addition, the viscosity of the $\mathrm{R}_{2} \mathrm{O} \cdot 2 \mathrm{SiO}_{2}$ $(\mathrm{R}=\mathrm{Li}, \mathrm{Na}, \mathrm{K})$ melts decreased upon the addition of $\mathrm{Fe}_{\mathrm{x}} \mathrm{O}$ because a part of iron ions act as the network modifier $\left(\mathrm{Fe}^{2+}\right.$ and $\left.\mathrm{Fe}^{3+}(6)\right)$. It was found that the decrease in the viscosity with increasing amount of $\mathrm{Fe}_{\mathrm{x}} \mathrm{O}$ is smaller in the larger alkali cation systems. $\mathrm{Fe}_{2} \mathrm{O}_{3}$ is known as an amphoteric oxide, and its behavior depends on the basicity of the system to which it is added. In a highly basic system (with a large alkali cation), $\mathrm{Fe}_{2} \mathrm{O}_{3}$ coordinates to four oxygen ions $\left(\mathrm{Fe}^{3+}(4)\right)$ and behaves as a network former, while it coordinates to six oxygen ions $\left(\mathrm{Fe}^{3+}(6)\right)$ and behaves as a network modifier when the basicity of the system is lower. Morinaga et al. ${ }^{26)}$ examined the $\mathrm{Fe}^{3+}$ coordination in $30 \mathrm{R}_{2} \mathrm{O}-60 \mathrm{SiO}_{2}-$ $10 \mathrm{Fe}_{2} \mathrm{O}_{3}(\mathrm{~mol} \%)$ glasses using Mössbauer spectroscopy. Figure 7 shows the relationship between the ratio of $\mathrm{Fe}^{3+}(4)$ to total- $\mathrm{Fe}^{3+}$ in the $30 \mathrm{R}_{2} \mathrm{O}-60 \mathrm{SiO}_{2}-10 \mathrm{Fe}_{2} \mathrm{O}_{3}(\mathrm{~mol} \%)$ glasses and the theoretical optical basicity of the solvent system, ${ }^{29)}$

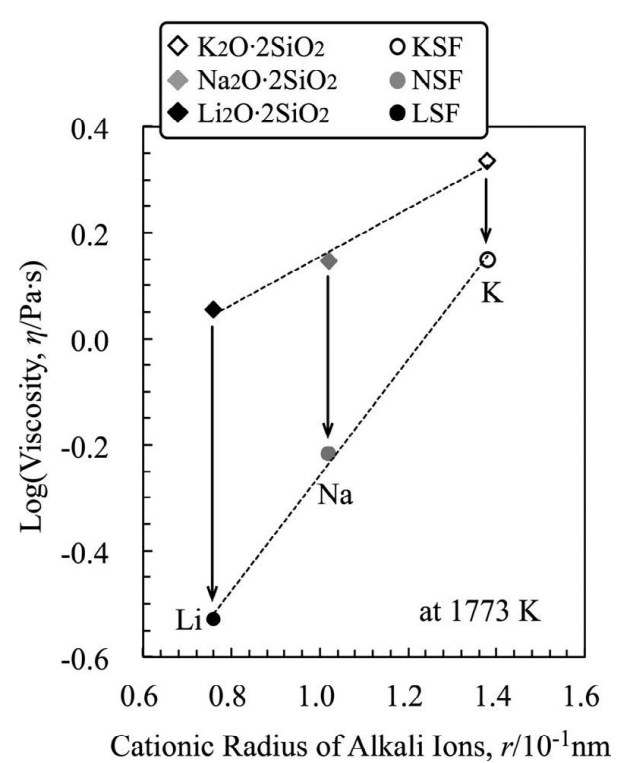

Fig. 6. Relationship between the viscosity of the $\mathrm{R}_{2} \mathrm{O}-\mathrm{SiO}_{2}-\mathrm{Fe}_{\mathrm{x}} \mathrm{O}$ $(\mathrm{R}=\mathrm{Li}, \mathrm{Na}, \mathrm{K})$ melts $\left(\mathrm{Fe}^{2+} /\right.$ total- $\left.\mathrm{Fe}=0.3\right)$ and the cationic radius of the alkali ions at $1773 \mathrm{~K}$, compared with that of the $\mathrm{R}_{2} \mathrm{O} \cdot 2 \mathrm{SiO}_{2}(\mathrm{R}=\mathrm{Li}, \mathrm{Na}, \mathrm{K})$ system, ${ }^{30)}$ which is the solvent of the present $\mathrm{R}_{2} \mathrm{O}-\mathrm{SiO}_{2}-\mathrm{Fe}_{\mathrm{x}} \mathrm{O}$ system. The viscosities of the $\mathrm{R}_{2} \mathrm{O}-\mathrm{SiO}_{2}-\mathrm{Fe}_{\mathrm{x}} \mathrm{O}$ melts with $\mathrm{Fe}^{2+} /$ total- $\mathrm{Fe}=0.3$ were calculated by interpolation of the relationship between the viscosity of the melts and the ratio of $\mathrm{Fe}^{2+}$ to total-Fe (shown in Fig. 5). Arrows in the figure represent rough measures of the decrease in viscosity upon addition of $\mathrm{Fe}_{\mathrm{x}} \mathrm{O}$ to the $\mathrm{R}_{2} \mathrm{O} \cdot 2 \mathrm{SiO}_{2}(\mathrm{R}=\mathrm{Li}, \mathrm{Na}, \mathrm{K})$ system. We employed the cationic radii of alkali cations reported by Shannon. ${ }^{31)}$ 


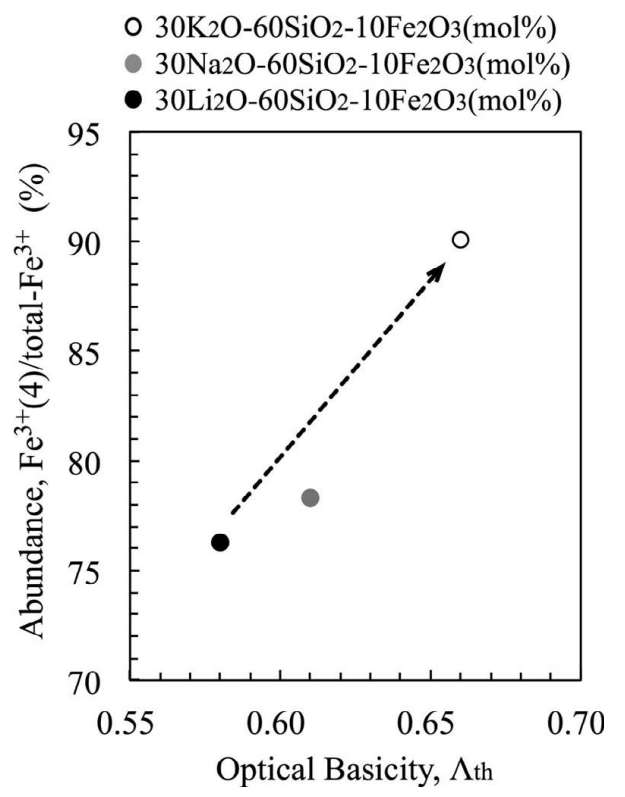

Fig. 7. Relationship between the ratio of $\mathrm{Fe}^{3+}(4)$ to total- $\mathrm{Fe}^{3+}$ in the $30 \mathrm{R}_{2} \mathrm{O}-60 \mathrm{SiO}_{2}-10 \mathrm{Fe}_{2} \mathrm{O}_{3}(\mathrm{~mol} \%)$ glasses and the theoretical optical basicity of the $\mathrm{R}_{2} \mathrm{O} \cdot 2 \mathrm{SiO}_{2}(\mathrm{R}=\mathrm{Li}, \mathrm{Na}, \mathrm{K})$ system. ${ }^{29)}$ Morinaga et al $^{26)}$ determined the fractions of $\mathrm{Fe}^{3+}(4)$ and $\mathrm{Fe}^{3+}(6)$ ions using Mössbauer spectroscopy. In their study, no $\mathrm{Fe}^{2+}$ ions could be detected in glasses that were melted for 6 hours under air before quenching; the melting temperatures of the samples were not described in their paper.

namely, $\mathrm{R}_{2} \mathrm{O} \cdot 2 \mathrm{SiO}_{2}(\mathrm{R}=\mathrm{Li}, \mathrm{Na}, \mathrm{K})$. The ratio of $\mathrm{Fe}^{3+}(4)$ to total- $\mathrm{Fe}^{3+}$ increased with increasing optical basicity, as shown in Fig. 7. This is the reason why the decrease in the viscosity of $\mathrm{R}_{2} \mathrm{O} \cdot 2 \mathrm{SiO}_{2}(\mathrm{R}=\mathrm{Li}, \mathrm{Na}, \mathrm{K})$ melts upon the addition of $\mathrm{Fe}_{\mathrm{x}} \mathrm{O}$ was the smaller in the systems containing larger alkali cations. It should be mentioned that the change in the viscosity of the silicate melts upon addition of $\mathrm{Fe}_{\mathrm{x}} \mathrm{O}$ is dominated not only by the oxidation state of the iron ions but also by the coordination structure of the $\mathrm{Fe}^{3+}$ ions. The coordination structure of $\mathrm{Fe}^{3+}$ is also strongly affected by the basicity of the system to which it is added.

Therefore, observations of the changes in the coordination structure of $\mathrm{Fe}^{3+}$ for different oxidation states of iron ions are strongly desired as future works in order to quantify the contribution of each Fe species on the viscosity.

\section{Conclusion}

We observed the viscosity changes for different oxidation states of iron ions in $\mathrm{R}_{2} \mathrm{O}-\mathrm{SiO}_{2}-\mathrm{Fe}_{\mathrm{x}} \mathrm{O}(\mathrm{R}=\mathrm{Li}, \mathrm{Na}$, or $\mathrm{K})$ melts using the rotating cylinder method. It was found that the ratio of $\mathrm{Fe}^{3+}$ to $\mathrm{Fe}^{2+}$ in the $\mathrm{R}_{2} \mathrm{O}-\mathrm{SiO}_{2}-\mathrm{Fe}_{\mathrm{x}} \mathrm{O}(\mathrm{mol} \%)$ glasses increased with increasing oxygen partial pressure for all samples. In addition, the ratio of $\mathrm{Fe}^{3+}$ to $\mathrm{Fe}^{2+}$ increased in the order of the alkali cationic radius $(\mathrm{K}>\mathrm{Na}>\mathrm{Li})$ when the oxygen partial pressures were comparable. The viscosity of all the $\mathrm{R}_{2} \mathrm{O}-\mathrm{SiO}_{2}-\mathrm{Fe}_{\mathrm{x}} \mathrm{O}$ melts decreased with increasing ratios of $\mathrm{Fe}^{2+}$ to total-Fe. The data indicate that $\mathrm{Fe}^{2+}$ ions behave as network modifiers in the silicate melts. In addition, the viscosity of the melts increased in the order of the alkali cationic radius $(\mathrm{K}>\mathrm{Na}>\mathrm{Li})$ when the ratio of $\mathrm{Fe}^{2+}$ to $\mathrm{Fe}^{3+}$ in the melts was comparable. This is due to the change in the coordination structure of $\mathrm{Fe}^{3+}$ in these melts.

\section{Acknowledgement}

This research was financially supported by the $17^{\text {th }}$ ISIJ research promotion grant. We would like to thank an anonymous reviewer for constructive and helpful comments on this manuscript.

\section{REFERENCES}

1) I. Jimbo, O. Ogawa and S. Goto: J. Min. Metall. Inst. Jpn., 98 (1982), 969.

2) D. B. Dingwell, M. Brearley and J. E. Dickinson, Jr.: Geochim. Cosmochim. Acta, 52 (1988), 2467.

3) D. B. Dingwell and M. Brearley: Geochim. Cosmochim. Acta, 52 (1988), 2815.

4) S. Hara, K. Irie, D. R. Gaskell and K. Ogino: Trans. Jpn. Inst. Met., 29 (1988), 977.

5) S. Hara, K. Irie, D. R. Gaskell and K. Ogino: Trans. Jpn. Inst. Met., 29 (1988), 990.

6) R. A. Lange and I. S. E. Carmichael: Geochim. Cosmochim. Acta, 53 (1989), 2195.

7) V. C. Kress and I. S. E. Carmichael: Geochim. Cosmochim. Acta, 53 (1989), 2883.

8) J. A. Tangeman, R. Lange and L. Forman: Geochim. Cosmochim. Acta, 65 (2001), 1809.

9) H. Larson and J. Chipman: J. Met., 5 (1953), 1089

10) F. Pinakidou, M. Katsikini, E. C. Paloura, O. Kalogirou and A. Erko: J. Non-Cryst. Solids, 353 (2007), 2717.

11) D. Holland, A. Mekki, I. A. Gee, C. F. McConville, J. A. Johnson, C. E. Johnson, P. Appleyard and M. Thomas: J. Non-Cryst. Solids, 253 (1999), 192.

12) G. H. Kaiura, J. M. Toguri and G. Marchant: Can. Metall. Q., 16 (1977), 156.

13) K. Seki and F. Oeters: Trans. Iron Steel Inst. Jpn., 24 (1984), 445.

14) D. B. Dingwell: Am. Mineral., 76 (1991), 1560.

15) J. W. Nowok: Energ. Fuel., 9 (1995), 534.

16) S. Sumita, K. Morinaga and T. Yanagase: J. Jpn. Inst. Met., 46 (1982), 369

17) A. Jambon, H. Weber and O. Braun: Geochim. Cosmochim. Acta, 50 (1986), 401 .

18) P. Richet and Y. Bottinga: Geochim. Cosmochim. Acta, 49 (1985), 471.

19) E. Bourgue and P. Richet: Earth Planet. Sci. Lett., 193 (2001), 57.

20) S. Sukenaga, D. Nakata, T. Ichiki, N. Saito and K. Nakashima: J. Jpn. Inst. Met., 71 (2007), 1050.

21) N. Saito, D. Nakata, S. Sukenaga and K. Nakashima: Key Eng. Mater., 403 (2009), 69.

22) T. Iida and Y. Kita: Boundary, 10 (1996), 34.

23) S. Sukenaga: Doctoral thesis of Kyushu University, (2011).

24) M. Wilke, H. Behrens, D. J. M. Burkhard and S. Rossano: Chem. Geol., 189 (2002), 55.

25) S. Sukenaga, Y. Gonda, S. Yoshimura, N. Saito and K. Nakashima: ISIJ Int., 50 (2010), 195.

26) K. Morinaga, Y. Suginohara and T. Yanagase: J. Jpn. Inst. Met., 40 (1976), 480.

27) S. Sumita, Y. Matsumoto, K. Morinaga and T. Yanagase: Trans. Jpn. Inst. Met., 23 (1982), 360.

28) J. A. Duffy and M. D. Ingram: J. Am. Chem. Soc., 93 (1971), 6448.

29) J. A. Duffy: Geochim. Cosmochim. Acta, 57 (1993), 3961.

30) J. O’M. Bockris, J. D. Mackenzie and J. A. Kitchener: Trans. Faraday Soc., 51 (1955), 1734.

31) R. D. Shannon: Acta Cryst. A, 32 (1976), 751. 